\title{
VARIASI KANDUNGAN KIMIA MINYAK CENDANA (Santalum album Linn) DARI BERBAGAI PROVENANS DI INDONESIA
}

\author{
Variation of chemical compounds of sandalwood oil from various provenances in Indonesia
}

\author{
Liliek Haryjanto, Titis Budi Widowati, Sumardi, Ari Fiani, dan Yayan Hadiyan \\ Balai Besar Penelitian dan Pengembangan Bioteknologi dan Pemuliaan Tanaman Hutan \\ Jl. Palagan Tentara pelajar Km. 15, Purwobinangun, Pakem, Sleman, Yogyakarta, Indonesia \\ email: liek_ht@yahoo.com
}

Tanggal diterima: 26 September 2016, Tanggal direvisi: 14 November 2016, Disetujui terbit: 21 Juni 2017

\begin{abstract}
The quality of sandalwood (Santalum album Linn) oil primarily depends on the compound of two major sesquiterpenes ( $\alpha$-santalol and $\beta$-santalol). The aim of this research was to identify variation of chemical compounds of sandalwood oil from various provenances. Fifty four samples from 8 provenances and one land race taken from $13^{\text {th }}$ years old sandalwood planted at Gunungkidul, Yogyakarta Indonesia. Sandalwood powder were obtained by drilling tree at $10 \mathrm{~cm}$ above the ground horizontally. The samples were extracted with $n$-hexane solvent. Identification of chemical compounds of this essential oils were conducted by gas chromatography mass spectrometry analysis (GCMS). The GCMS investigation of sandalwood oils showed that variation compounds both among individual within provenance and between provenances were found in 11 individual from 6 provenances. Compounds such as sesquiterpene, monoterpenes, and others, were found in variying amount. The results showed that $\alpha$-santalol (32.38-78.29\%), $\beta$-santalol (5.45\%-37.83\%) were the major compounds with varying quantities of compounds range of epi- $\beta$-santalol (5.97-17.16\%), P-Menth-2-En-9-OL-Trans $(2.87 \%$ $8.53 \%)$, and $\alpha$-sinensal (3.83-9.39\%).
\end{abstract}

Keywords: essential oil, GCMS, $\alpha$-santalol, $\beta$-santalol

\begin{abstract}
ABSTRAK
Kualitas minyak cendana (Santalum album Linn) ditentukan oleh adanya 2 kandungan komponen Sesquiterpene, yakni $\alpha$-santalol dan $\beta$-santalol. Tujuan penelitian ini untuk mengetahui variasi kandungan kimia cendana dari berbagai provenans. Sebanyak 54 sampel dari 8 provenans dan satu ras lahan diambil dari tanaman cendana umur 13 tahun di Hutan Penelitian Watusipat, Gunungkidul, Yogyakarta. Serbuk kayu cendana didapatkan dengan cara mengebor batang cendana setinggi $10 \mathrm{~cm}$ di atas permukaan tanah. Serbuk diekstrasi dengan larutan n-hexane untuk mendapatkan larutan minyak. Kandungan kimia larutan cendana dianalisis menggunakan GCMS (gas chromatography mass spectrometry). Hasil analisis menunjukkan adanya variasi kandungan kimia baik antar provenans maupun individu dalam provenans yang ditemukan pada 11 sampel dari 6 provenans. Senyawa golongan Sesquiterpene, Monoterpene dan komponen kimia lainnya ditemukan dalam jumlah yang bervariasi. Komponen utama dari hasil pengujian adalah $\alpha$-santalol $(32,38 \%-78,29 \%)$ dan $\beta$-santalol $(5,45 \%-37,83 \%)$ diikuti oleh epi- $\beta$-santalol (5,97\%-17,16\%), P-Menth-2-En-9-OL-Trans (2,87\%-8,53\%) dan $\alpha$-sinensal (3,83\%-9,39\%).
\end{abstract}

Kata kunci: minyak esensial, GCMS, $\alpha$-santalol, $\beta$-santalol

\section{PENDAHULUAN}

Spesies cendana (Santalum album Linn) termasuk ke dalam Family Santalaceae dikenal sebagai East Indian Sandalwood, merupakan salah satu jenis yang paling tinggi nilai kayu teras dan minyak esensialnya (Misra, Das, \& Dey, 2013). Selain sebagai bahan baku utama pembuatan parfum, minyak cendana dapat digunakan untuk bahan kosmetik, obat-obatan dan aroma terapi. Kayu terasnya banyak digunakan untuk kerajinan seperti patung, ukiran, kipas, tasbih dan rosario (Haryjanto, 2009).

Sebaran alam cendana dijumpai di China, India, Indonesia, Phillipina (IUCN, 1998; McKinnel, 1993) dan Australia (Doran, Thomson, \& Brophy, 2002). Di Indonesia cendana dijumpai di kepulauan Indonesia Bagian Timur seperti P. Timor, P. Sumba, P. Alor, P. Rote dan P. Pantar. Pemanenan cendana tanpa diikuti dengan keberhasilan penanaman kembali mengakibatkan penurunan populasi cendana di Nusa Tenggara Timur (Sumardi \& Fiani, 2015). 
Hal ini mengakibatkan cendana masuk dalam kategori extinct in the wild di populasi alaminya (Ratnaningrum \& Indrioko, 2014).

Kualitas minyak cendana ditentukan oleh kandungan $\alpha$-santalol dan $\beta$-santalol. Senyawa $\alpha$-santalol dan $\beta$-santalol merupakan senyawa organik golongan sesquiterpene yang beraroma khas (Subasinghe, 2013; Subasinghe, Gamage, \& Hettiarachchi, 2013). Penelitian yang dilakukan Xiaojin, Daping, Zengjiang, Ningnan, dan Yang (2011) menyatakan bahwa kandungan $\alpha$ santalol, $\beta$-santalol, $\alpha$-trans-bergamotenol, cislanceol dan bycyclogermacrene terdapat pada cendana umur 6 tahun di Guangdong, China Selatan. Cendana umur 15 tahun di India mengandung $\alpha$-santalol, $\beta$-santalol, epi- $\beta$ santalalol, epi- $\beta$-santalene, $\alpha$-santalene, $\beta$ santalene dan $\alpha$-bergamotol (Bisht \& Hemanthraj, 2014). Cendana di Sri Lanka umur 15 tahun mengandung $\alpha$-trans-bergamotol, $\alpha$ -

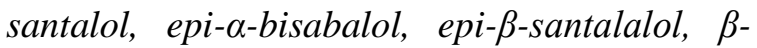
santalol, E,E-farnesol, nuciferol, $\gamma$-curcumen12-ol, $\quad \beta$-curcumen-12-ol dan lanceol (Subasinghe et al., 2013).

Menurut penelitian yang dilakukan oleh Brand, Kimber, dan Streatfield (2006); Doran et al. (2005); Moniodis et al. (2012); Xiaojin et al. (2011); Day (2012), dan Hettiarachchi (2008), pada $S$. album, $S$. spicatum, $S$. yasi, $S$. austrocaledonicum terdapat variasi kandungan $\alpha$-santalol dan $\beta$-santalol pada level individu jenis yang sama, antar jenis, antar lokasi, variasi ukuran pohon dan cara ekstraksi yang berbeda. Namun demikian informasi faktor genetik yang mempengaruhi variasi kandungan $\alpha$-santalol dan $\beta$-santalol masih terbatas. Menurut Sinha (1961) dan Quémin (1988), asal provenans mempengaruhi kandungan minyak cendana.

Tujuan penelitian ini adalah untuk mengetahui variasi kandungan kimia cendana dan memilih individu unggul berdasarkan komponen utamanya yakni $\alpha$-santalol dan $\quad \beta$ santalol sebagai dasar pemuliaan genetik cendana.

\section{METODE PENELITIAN}

\section{A. Bahan}

Sebanyak 54 sampel cendana (umur 13 tahun) berasal dari 8 provenans dan 1 ras lahan (Tabel 1). Setiap provenans diambil sebanyak 6 pohon secara random pada bulan September 2015. Lokasi pengambilan sampel di Hutan Penelitian Balai Besar Penelitian dan Pengembangan Bioteknologi dan Pemuliaan Tanaman Hutan Watusipat, Gunungkidul, Yogyakarta (S ${ }^{\circ}$ ' 54' 07.0', E110 33' 28.4'”). Diskripsi lokasi: tipe iklim $\mathrm{C}$ dengan curah hujan $1894 \mathrm{~mm} /$ tahun, musim penghujan umumnya dimulai pada bulan Oktober dan menurun pada bulan Maret. Topografi datar bergelombang dengan kelerengan berkisar 5\% - 50\%. Jenis tanah gromosol hitam, bahan induk napal dan tufvulkan dengan tingkat kesuburan rendah. Ketinggian tempat \pm 150 meter di atas permukaan laut (Balai Besar Penelitian Bioteknologi dan Pemuliaan Tanaman Hutan, 2013).

Serbuk cendana didapatkan dengan cara mengebor batang cendana setinggi $10 \mathrm{~cm}$ di atas permukaan tanah. Pengeboran dilakukan secara horisontal dari sisi satu sampai tembus sisi yang lainnya. Sebanyak 3 gram serbuk kayu dihaluskan dan dikeringkan, kemudian dimasukkan ke dalam botol dan ditambah larutan n-Hexane sebanyak 2 kali berat sampel. Sampel di-vortex selama 1 menit setiap 3 jam sekali (diulangi sebanyak 3 kali) kemudian disaring. Larutan minyak dalam hexane kemudian dipekatkan 10 kali dengan gas nitrogen.

\section{B. Analisis kimia}

Analisis kimia minyak cendana menggunakan GCMS (gas chromatography mass spectrometry) (Howes, Simmonds, \& Kite, 2004). Larutan cendana dimasukan pada GCMS, komponen GC-2010 dipasangkan dengan GCMS-QP2010S (Shimadzu, Japan) menggunakan kolom Agilent Hp 1MS dengan panjang $30 \mathrm{~m}$; ID $0,25 \mathrm{~mm}$ dan ketebalan film 0,25 $\mu \mathrm{m}$; gas pembawa Helium; Ion Ei $70 \mathrm{Ev}$. 
Perlakuan pada GC-2010 sebagai berikut: suhu kolom $70^{\circ} \mathrm{C}$, suhu injeksi $300^{\circ} \mathrm{C}$ dengan mode splitless; tekanan $13,7 \mathrm{kPa}$; total flow 37,5 $\mathrm{mL} / \mathrm{ml}$; linear velocity $25,9 \mathrm{~cm} / \mathrm{sec}$; purge flow $3,0 \mathrm{~mL} / \mathrm{min}$ dan split ratio sebesar 68 . Perlakuan pada GC-MS-QP2010 sebagai berikut suhu ion source $250^{\circ} \mathrm{C}$; suhu interface $300^{\circ} \mathrm{C}$; solvent cut time 3,5 menit; detector gain $1,4 \mathrm{kV}$ dengan mode Absolute. MS tabel mengikuti ketentuan start time 3,6 min; end time $60 \mathrm{~min}$; mode AQC Scan; event time 0,50 sec; scan speed 1250; start $\mathrm{m} / \mathrm{z} 28$ dan end m/z 600 .

Tabel 1. Data lokasi asal provenans cendana

\begin{tabular}{|c|c|c|c|}
\hline $\begin{array}{l}\text { Nomor } \\
\text { seedlot }\end{array}$ & Provenans & Letak Geografis & $\begin{array}{c}\text { Ketinggian } \\
\text { Tempat } \\
(\mathrm{m} \mathrm{dpl})\end{array}$ \\
\hline P3 & Hambala (P. Sumba) & $9^{\circ} 44^{\prime} 21.70^{\prime \prime} \mathrm{S}$ dan $120^{\circ} 15^{\prime} 21.05^{\prime \prime} \mathrm{E}$ & 194 \\
\hline P4 & Katikutana (P. Sumba) & $9^{\circ} 34^{\prime} 55.80^{\prime \prime} \mathrm{S}$ dan $119^{\circ} 32^{\prime} 32.39^{\prime \prime} \mathrm{E}$ & 370 \\
\hline P5 & Waisika (P. Alor) & $8^{\circ} 12^{\prime} 24.97^{\prime \prime} \mathrm{S}$ dan $124^{\circ} 45^{\prime} 47.18^{\prime \prime} \mathrm{E}$ & 587 \\
\hline P6 & Pailelang (P. Alor) & $8^{\circ} 18^{\prime} 05.98^{\prime \prime} \mathrm{S}$ dan $124^{\circ} 33^{\prime} 28.15^{\prime \prime} \mathrm{E}$ & 452 \\
\hline P7 & Kuma, Mollo Selatan, TTS (P. Timor) & $9^{\circ} 51^{\prime} 47.18^{\prime \prime} \mathrm{S}$ dan $124^{\circ} 13^{\prime} 10.81^{\prime \prime} \mathrm{E}$ & 580 \\
\hline P8 & Pollen, Mollo Selatan, TTS (P. Timor) & $9^{\circ} 39^{\prime} 35.60^{\prime \prime} \mathrm{S}$ dan $124^{\circ} 22 ' 22.83^{\prime \prime} \mathrm{E}$ & 647 \\
\hline P 16 & Snok, Amanatun Utara, TTS (P. Timor) & $9^{\circ} 41^{\prime} 28.96 " \mathrm{~S}$ dan $124^{\circ} 40^{\prime} 04.11^{\prime \prime} \mathrm{E}$ & 320 \\
\hline $\mathrm{P} 17$ & Noemuti, Miomafo Timur, TTU (P. Timor) & $9^{\circ} 35^{\prime} 36.84^{\prime \prime} \mathrm{S}$ dan $124^{\circ} 29^{\prime} 32.34^{\prime \prime} \mathrm{E}$ & 492 \\
\hline $\mathrm{P} 10$ & Karangmojo, Gunungkidul (ras lahan) & $7^{\circ} 55^{\prime} 54.11 " \mathrm{~S}$ dan $110^{\circ} 40^{\prime} 39.09^{\prime \prime} \mathrm{E}$ & 175 \\
\hline
\end{tabular}

\section{Analisis statistik}

Untuk mengetahui kekuatan hubungan antara keliling batang (x) dengan kandungan santalol (y) digunakan analisis korelasi dari Pearson:

Korelasi $=r_{x y}=\frac{\sum\left(x_{i}-\bar{x}\right)\left(y_{i}-\bar{y}\right)}{\sqrt{\sum\left(x_{i}-\bar{x}\right)^{2}} \cdot \sqrt{\sum\left(y_{i}-\bar{y}\right)^{2}}}$

Keterangan:

$$
\begin{aligned}
\mathrm{r}_{\mathrm{xy}}= & \text { koefisien korelasi antara variabel } \mathrm{x} \text { dan } \\
& \text { variabel } \mathrm{y} \\
\mathrm{x}_{\mathrm{i}}= & \text { nilai pengamatan variabel } \mathrm{x} \text { ke- } \mathrm{i} \\
\mathrm{y}_{\mathrm{i}}= & \text { nilai pengamatan variabel } \mathrm{y} \mathrm{ke}-\mathrm{i} \\
\bar{x} & =\text { rerata variabel } \mathrm{x} \\
\bar{y} & =\text { rerata variabel } \mathrm{y}
\end{aligned}
$$

Analisis varians digunakan untuk mengetahui pengaruh provenans terhadap kandungan santalol.

Analisis data menggunakan SPSS versi 16.00 .

\section{HASIL DAN PEMBAHASAN}

\section{A. Variasi kandungan kimia antar dan dalam provenans}

Dari 54 sampel yang diuji hanya 11 sampel yang dapat diidentifikasi kandungan kimianya yang berasal dari 5 provenans yakni Hambala, Pailelang, Waisika, Noemuti, dan Pollen serta 1 ras lahan yakni Karangmojo. Hal ini menunjukkan terdapat variasi kandungan kimia antar provenans cendana. Perbedaan lingkungan tumbuh asal provenans dapat menjadi penggerak utama dalam proses perbedaan susunan genetik karena adaptasi lokal (Frankel, 1970). Komponen utama dari hasil pengujian ini adalah $\alpha$-santalol dan $\beta$-santalol diikuti oleh epi- $\beta$-santalol, $P$-Menth-2-En-9-OLTrans dan $\alpha$-sinensal (Tabel 2). Variasi kandungan kimia pada tanaman cendana juga dijumpai di beberapa negara dengan $\alpha$-santalol dan $\beta$-santalol merupakan komponen utamanya seperti disajikan pada Tabel 3 . 
Tabel 2. Kandungan kimia cendana dari 5 provenans dan 1 ras lahan

\begin{tabular}{|c|c|c|c|c|c|c|c|c|c|c|c|}
\hline \multirow[t]{2}{*}{ Kandungan kimia } & \multirow{2}{*}{$\begin{array}{c}\text { Hambala, } \\
\text { P. Sumba } \\
\text { P3.1 }\end{array}$} & \multicolumn{3}{|c|}{$\begin{array}{l}\text { Pailelang } \\
\text { P. Alor }\end{array}$} & \multirow{2}{*}{$\begin{array}{c}\text { Karangmojo } \\
\text { P10.19 } \\
\end{array}$} & \multicolumn{2}{|c|}{$\begin{array}{c}\text { Waisika } \\
\text { Alor }\end{array}$} & \multicolumn{2}{|c|}{$\begin{array}{l}\text { Noemuti, } \\
\text { TTU Timor }\end{array}$} & \multicolumn{2}{|c|}{$\begin{array}{l}\text { Pollen, } \\
\text { TTS Timor }\end{array}$} \\
\hline & & P6.1 & P6.11 & P6.15 & & $\begin{array}{l}\text { P5.2 } \\
\end{array}$ & P5.4 & P17.3 & P17.19 & P8.1 & P8.4 \\
\hline \multicolumn{12}{|l|}{ Sesquiterpene } \\
\hline$\alpha-$ Santalol & 75,23 & 78,29 & 32,38 & 63,79 & 38,87 & 51,26 & 48,06 & 52,83 & 61,5 & 46,54 & 49,37 \\
\hline$\beta$-Santalol & 5,45 & 21,72 & 22,08 & 35,89 & 37,83 & 7,60 & 20,12 & 18,57 & 20,08 & 16,45 & 18,37 \\
\hline epi- $\beta$-Santalol & - & - & 5,97 & - & - & 17,16 & 7,48 & 7,38 & 7,43 & 8,57 & 7,23 \\
\hline$\alpha$-Sinensal & - & - & 9,39 & - & 9,36 & - & 3,83 & - & 5,12 & - & 3,92 \\
\hline$\beta$-Sinensal & - & - & - & - & - & 4,63 & - & 3,72 & - & 5,02 & - \\
\hline$\alpha$-Santalene & - & - & - & - & 0,45 & 1,19 & 1,08 & 1,27 & - & - & - \\
\hline$\beta$-Santalene & - & - & - & - & 0,87 & 2,16 & 1,69 & 2,10 & - & 2,50 & - \\
\hline epi- $\beta$-Santalene & - & - & - & - & 0,60 & 0,94 & - & 1,47 & - & - & 0,98 \\
\hline$\alpha$-Curcumene & - & - & 4,92 & - & 9,92 & - & 1,15 & - & - & - & - \\
\hline Zingiberene & - & - & 3,83 & - & - & - & 2,59 & 2,87 & - & 3,80 & 3,03 \\
\hline Bycyclogermacrene & - & - & - & - & - & - & - & 1,21 & - & 2,89 & 2,59 \\
\hline Bicyclo2.2.1 heptane,2-methyl-3-methylene-2-(-4methyl-3-pentenyl) & - & - & - & - & - & - & - & - & - & - & 1,94 \\
\hline $\begin{array}{l}\text { 2-Penten-1-ol,2-methyl-5-(2-methylene bicyclo } 2.2 .1 \text { hept-2-yl),1s- } \\
\text { 1alpha.,2alpha.,(z) } 4 \text { alpha }\end{array}$ & 19,32 & - & - & - & 1,85 & - & - & - & - & - & - \\
\hline Caryophyllene oxide & - & - & - & - & - & - & - & 3,12 & - & - & - \\
\hline \multicolumn{12}{|l|}{ Monoterpene } \\
\hline p-Mentha-1(7),8(10)-dien-9-ol & - & - & 5,40 & - & - & - & 2,87 & - & - & 3,08 & 8,53 \\
\hline Sabinol & - & - & 7,83 & - & - & - & - & - & - & & - \\
\hline P-Menth-2-En-9-OL,Trans & - & - & - & - & - & 6,74 & 8,8 & 5,46 & 5,87 & 6,03 & 4,04 \\
\hline$\alpha$-Cyclocitral & - & - & - & - & - & - & - & - & - & 5,13 & - \\
\hline 2-Cyclohexene-1-carboxaldehyde,2,6,6-trimethyl & - & - & - & - & - & 4,95 & - & - & - & - & - \\
\hline \multicolumn{12}{|l|}{ Other } \\
\hline Dibutyl phthalate & - & - & 5,20 & - & - & - & - & - & - & - & - \\
\hline Argon & - & - & - & 0,32 & - & - & - & - & - & - & - \\
\hline 1,5-Cycloundecadiene,8,8-dimethyl-9-methylene & - & - & - & - & - & 3,38 & 2,33 & - & - & - & - \\
\hline Kauran-18-al,17-(acetyloxy)-(4 beta) & - & - & - & - & 0,36 & - & - & - & - & - & - \\
\hline 2-hexanone,3-methyl-4-methylene & - & - & 2,99 & - & - & - & - & - & - & - & - \\
\hline
\end{tabular}


Tabel 3. Rerata beberapa kandungan kimia pada tanaman cendana dari beberapa negara

\begin{tabular}{lcccc}
\hline \multirow{2}{*}{ Kandungan kimia } & \multicolumn{4}{c}{ Asal negara/umur (tahun) } \\
\cline { 2 - 5 } & $\begin{array}{c}\text { Guangdong, } \\
\text { China/6 }\end{array}$ & Sri Lanka/15 & $\begin{array}{c}\text { Bangalor, } \\
\text { India/15 }\end{array}$ & Indonesia/13 $^{\mathrm{d}}$ \\
\hline$\alpha$-Santalol & 18,62 & 31,51 & 34,60 & 54,37 \\
$\beta$-Santalol & 9,82 & 14,38 & 17,69 & 20,38 \\
epi- $\beta$-Santalol & 0,80 & 2,13 & 2,70 & 8,74 \\
$\alpha-$ Santalene & 0,51 & - & 0,90 & 0,99 \\
$\beta-$ Santalene & 0,60 & - & 1,64 & 1,86 \\
epi- $\beta$-Santalene & 0,46 & - & 1,05 & 0,99 \\
\hline
\end{tabular}

Keterangan:

$$
\begin{aligned}
& \mathrm{a}=\text { Xiaojin et al. }(2011) \\
& \mathrm{b}=\text { Subasinghe et al. }(2013) \\
& \mathrm{c}=\text { Bisht \& Hemanthraj (2014) } \\
& \mathrm{d}=\text { Penelitian ini }
\end{aligned}
$$

Disamping variasi antar provenans, variasi kandungan kimia juga terdapat pada individu dalam provenans. Variasi antar individu dalam provenan yang dapat diidentifikasi kandungan kimianya sebagai berikut: provenans Hambala dan ras lahan Karangmojo ada 1 individu $(16,66 \%)$, provenans Pailelang ada 3 individu (50\%), provenans Waisika, Noemuti dan Pollen terdapat masing-masing 2 individu $(33,33 \%)$ seperti disajikan pada Tabel 4. Individu P17.3 memiliki kandungan kimiawi golongan sesquiterpene terbanyak (10 jenis), sedangkan individu P6.1 paling sedikit yaitu 2 jenis. Untuk golongan monoterpene bervariasi antara 1-3 jenis setiap individunya.

Tabel 4. Golongan kandungan kimia cendana dari beberapa provenans

\begin{tabular}{lcccc}
\hline \multicolumn{1}{c}{ Provenans } & Individu & Sesquiterpene & Monoterpene & Lainnya \\
\hline Hambala (P3) & P3.1 & 3 & - & - \\
Pailelang (P6) & P6.1 & 2 & - & - \\
& P6.11 & 6 & 2 & 2 \\
Karangmojo (P10) & P6.15 & 2 & - & 1 \\
Waisika (P5) & P10.19 & 8 & - & 1 \\
Noemuti (P17) & P5.2 & 7 & 2 & 1 \\
P5.4 & P17.3 & 8 & 2 & 1 \\
Pollen (P8) & P17.19 & 10 & 1 & - \\
& P8.1 & 4 & 3 & - \\
\hline
\end{tabular}

Meskipun ada variasi antar provenans dan individu dalam provenans, namun secara statistik variasi komponen utama ( $\alpha$-santalol dan $\beta$ santalol) tersebut tidak signifikan yang ditunjukkan pada Tabel 5. Kandungan lainnya seperti epi- $\beta$-Santalol, P-Menth-2-En-9-OLTrans dan $\alpha$-sinensal tidak dapat dilakukan analisis varians mengingat individu yang mengandung ketiga kandungan kimia tersebut terbatas jumlahnya yaitu masing-masing sebanyak 7, 6 dan 5 individu.
Tidak signifikansnya variasi kandungan $\alpha$ santalol dan $\beta$-santalol baik antar provenans maupun individu dalam provenans, maka strategi pemuliaan maupun perkawinan silang di masa mendatang dilakukan tanpa mempertimbangkan asal provenans dan hanya memilih individuindividu yang memiliki kandungan santalol tinggi. Adanya variasi kandungan kimiawi minyak cendana menunjukkan dimungkinkan untuk dilakukan pemuliaan untuk meningkatkan kualitas minyak. 
Tabel 5. Analisis varians kandungan $\alpha$-santalol dan $\beta$-santalol

\begin{tabular}{lccc}
\hline \multirow{2}{*}{ Sumber variasi } & \multirow{2}{*}{ Derajat bebas } & \multicolumn{2}{c}{ Kuadrat Tengah } \\
\cline { 3 - 4 } & & $\alpha$-santalol & $\beta$-santalol \\
\hline Provenans & 3 & $85,39 \mathrm{~ns}$ & $20,31 \mathrm{~ns}$ \\
Individu (provenans) & 4 & $275,14 \mathrm{~ns}$ & $45,44 \mathrm{~ns}$ \\
Galat & & 47,66 & 30,15 \\
\hline
\end{tabular}

Keterangan: $\mathrm{ns}=$ tidak berbeda nyata pada taraf uji $5 \%$

\section{B. Kandungan santalol}

Kualitas minyak cendana ditentukan oleh kandungan $\alpha$-santalol dan $\beta$-santalol. Dari 54 individu, hanya ada 11 individu yang dapat diidentifikasikan kandungan kimianya memiliki rerata $\alpha$-santalol sebesar $54,37 \%$ dan $\beta$-santalol 20,38\% (Tabel 6). Dari hasil penelitian diketahui bahwa kandungan $\alpha$-santalol dan $\beta$-santalol cendana umur 13 tahun lebih tinggi dibandingkan cendana umur 15 tahun dari berbagai lokasi. Rerata kandungan $\alpha$-santalol dan $\beta$-santalol di Bangalore India masingmasing $34,60 \%$ dan $17,69 \%$ (Bisht \& Hemanthraj, 2014), di Sri Lanka 31,51\% dan 14,38\% (Subasinghe et al., 2013). Cendana di Australia pada umur 15 tahun kandungan $\alpha$ santalolnya $42,8 \%$, sedangkan $\beta$-santalol sedikit lebih besar yaitu 22,4\% (Brand, Fox, Pronk, \& Cornwell, 2007). Dari 11 individu tersebut, sebanyak 7 individu yang memenuhi standar ISO 35182002 (Gambar 1). Pada perdagangan internasional, kandungan $\alpha$-santalol dan $\beta$ santalol standart ISO untuk $S$. album yaitu 41$55 \% \alpha$-santalol dan $16-24 \% \quad \beta$-santalol (ISO 3518, 2002).

Untuk mengetahui kekuatan hubungan antara kandungan santalol dengan keliling batang digunakan analisis korelasi. Hasil analisis menunjukkan tidak terdapat hubungan yang kuat antara besar keliling batang dengan kandungan $\alpha$-santalol maupun $\beta$-santalol seperti ditunjukkan dengan rendahnya koefisien determinasi $\left(\mathrm{R}^{2}\right)$ masing-masing sebesar 0,08 dan 0,21 (Gambar 2). Hal yang sama juga dikemukakan (Bisht \& Hemanthraj, 2014).

\section{Implikasi untuk pemuliaan cendana}

Variasi kandungan kimia pada minyak cendana yang ditemukan baik antar individu dalam provenans maupun antar provenans yang diteliti memungkinkan untuk dilakukan pemuliaan genetik melalui seleksi pada individuindividu tersebut. Pada individu-individu yang memenuhi standart ISO 35182002 dapat diperbanyak dengan kultur jaringan (Sanjaya, Bagyalakshmi, Thrilok, \& Vittal, 2006a; Janarthanam, Dhamotharan, \& Sumanthi, 2012; Singh, Raj, Patil, Jaiswal, \& Subhash, 2013; Peeris \& Senarath, 2015) maupun mikro grafting (Sanjaya, Bagyalakshmi, Thrilok, \& Vittal, 2006b). Teknik tersebut mampu menjaga potensi keunggulan sifat induknya karena seluruh sifat induknya akan diturunkan semua pada tanaman hasil perbanyakannya. Individu superior ini juga dapat menjadi sumber materi genetik untuk produksi scion yang bermanfaat untuk membuat kebun benih klon.

Strategi pemuliaan cendana berikutnya adalah dilakukan perkawinan silang antar individu superior. Persilangan ini memiliki 2 tujuan: (1) meningkatkan variasi genetik populasi dan (2) mendapatkan benih dengan kualitas yang lebih baik dibandingkan induknya. Sistem penyerbukan cendana yang outcrossing (Baskorowati, 2011; Rugkhla \& Mccomb, 1993) menguntungkan untuk menjaga keragaman genetik, mengingat cendana yang mengandung santalol hanya 11 individu. 
Tabel 6. Keliling pohon dan kandungan $\alpha$-santalol dan $\beta$-santalol

\begin{tabular}{clccc}
\hline \multirow{2}{*}{ No.Individu } & Provenans & Keliling Pohon $(\mathrm{cm})$ & \multicolumn{2}{c}{ Kandungan } \\
\hline 1 & Hambala & 31,0 & 75,23 & 5,45 \\
2 & Pailelang & 22,0 & 78,29 & 21,72 \\
3 & Pailelang & 14.3 & 32,38 & 22,08 \\
4 & Pailelang & 21.3 & 63,79 & 35,89 \\
5 & Waisika & 32,0 & 51,26 & 7,60 \\
6 & Waisika & 36,0 & 48,06 & 20,12 \\
7 & Noemuti & 22,0 & 52,83 & 18,57 \\
8 & Noemuti & 20,0 & 61,5 & 20,08 \\
9 & Pollen & 20,0 & 46,54 & 16,45 \\
10 & Pollen & 20,0 & 49,37 & 18,37 \\
11 & Karangmojo & 21,0 & 38,87 & 37,83 \\
\hline Rerata & & 23,60 & 54,37 & 20,38 \\
\hline
\end{tabular}

Catatan: Keliling diukur 0,1 $\mathrm{m}$ di atas permukaan tanah

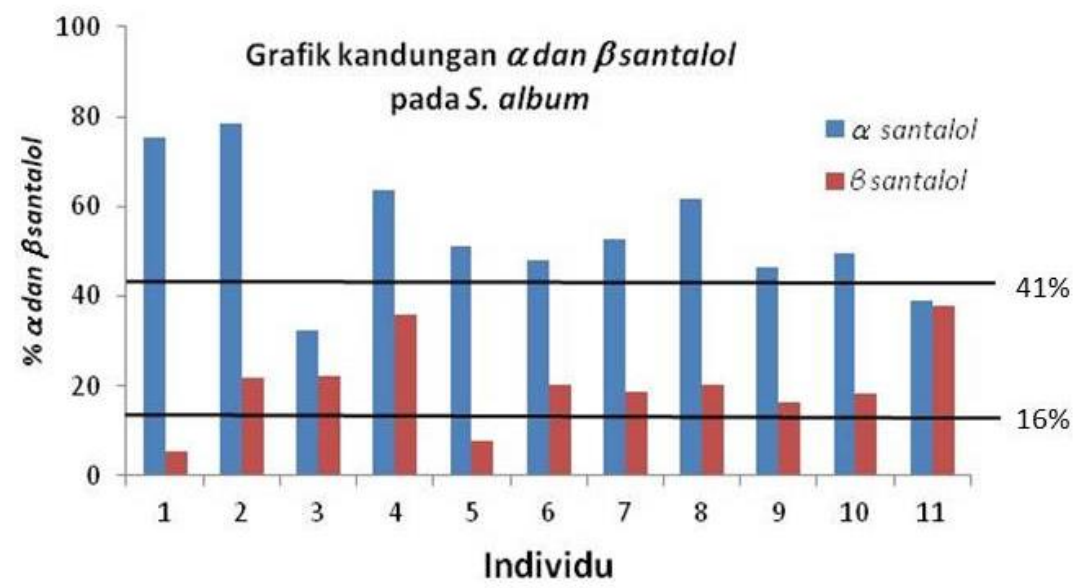

Gambar 1. Tujuh individu (2, 4, 6, 7, 8, 9, 10) memenuhi standar ISO 35182002
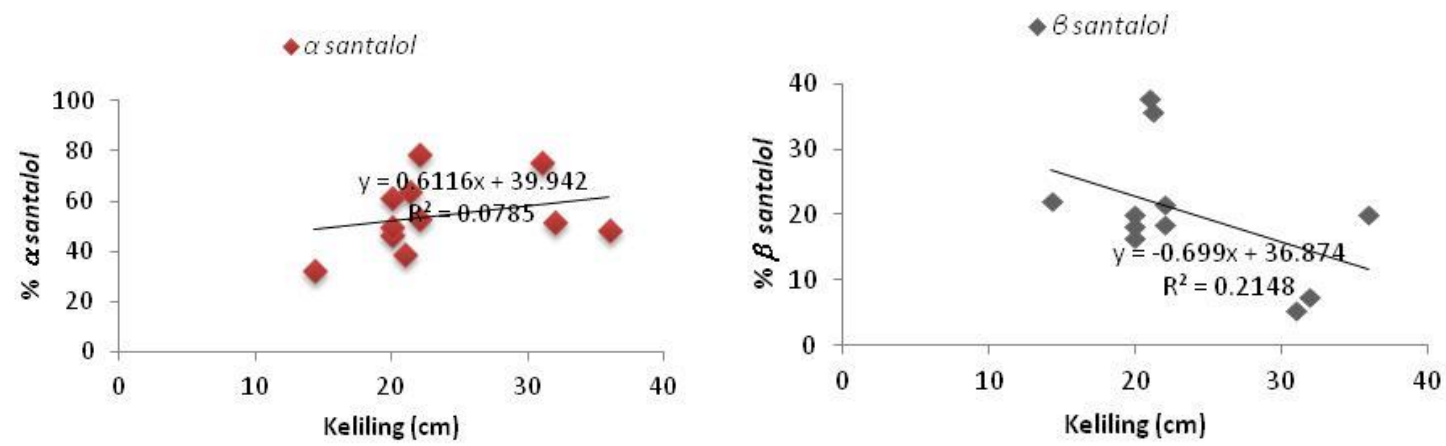

Gambar 2. Regresi keliling batang dengan kandungan $\alpha$-santalol dan $\beta$-santalol 


\section{KESIMPULAN}

Kandungan $\alpha$-santalol dan $\beta$-santalol minyak cendana bervariasi antar provenans maupun individu dalam provenans, namun tidak menunjukkan perbedaan yang signifikan. Oleh sebab itu seleksi individu dengan kandungan $\alpha$ santalol dan $\beta$-santalol tinggi tanpa memperhatikan asal provenans menjadi strategi pemuliaan terbaik untuk mendapatkan benih unggul.

\section{UCAPAN TERIMA KASIH}

Ucapan terima kasih disampaikan kepada Yuliah, M.Sc atas dedikasinya sebagai penanggung jawab kegiatan konservasi ex situ cendana di Watusipat (2004-2009); Subagyo, petugas lapangan yang membantu pengamanan tanaman cendana; Sudrajat, Arif Setiawan, S.Hut, Teknisi kegiatan cendana BBPPBPTH, dan Sudomo, laboran Fak. MIPA UGM yang membantu proses analisis sampel.

\section{DAFTAR PUSTAKA}

Balai Besar Penelitian Bioteknologi dan Pemuliaan Tanaman Hutan. (2013). Sekilas tentang kawasan hutan dengan tujuan khusus Gunungkidul blok Watusipat. Profil KHDTK Gunungkidul Blok Watusipat. Yogyakarta.

Baskorowati, L. (2011). Implikasi biologi reproduksi terhadap konservasi genetik jenis Santalum album. Jurnal Pemuliaan Tanaman Hutan, 5(1), 1-11.

Bisht, S. S., \& Hemanthraj, K. P. M. (2014). Gas Chromatography-Sass Spectrometry ( GC-MS ) Profiling of Heartwood Oil Composition from 15 Years Old Sandalwood Trees. International Journal of Pharmacognosy and Phytochemical Research, 6(2), 387-392.

Brand, J. E., Fox, J. E. D., Pronk, G., \& Cornwell, C. (2007). Comparison of oil concentration and oil quality from Santalum spicatum and $S$. album plantations , $8-25$ years old, with those from mature $S$. spicatum natural stands. Australian Forestry, 70(4), 235-241.

Brand, J., Kimber, P., \& Streatfield, J. (2006). Preliminary analysis of Indian sandalwood oil from a 14 year old plantation at Kununurra, Western Australia. Sandalwood Research Newsletter, (21), 1-3.
Day, J. (2012). Musing of a sandalwood oil distiller. In International Sandalwood Symposium. Honolulu, Hawai: International Sandalwood Foundation.

Doran, J. C., Thomson, L. A. J., \& Brophy, J. J. (2002). Sandalwood. In Regional Workshop on Sandalwood Research, Development and Extention in the Pacific Islands and Asia (pp. 1-30). Noumea, New Caledonia.

Doran, J. C., Thomson, L., Brophy, J., Goldsack, B., Bulai, P., Faka'osi, T., \& Mokoia, T. (2005). Variation in heartwood oil composition of young sandalwood trees in the South Pacific (Santalum yasi, S. album and F1 hybrids in Fiji , and $S$. yasi in Tonga and Niue). Sandalwood Research Newsletter, (20), 3-7.

Frankel, 0. H. (1970). Genetic conservation in perspective. In O. H. Frankel \& E. Bennet (Eds.), Genetic resources in plant their exploration and conservation (p. 554). Oxford: Blackwell Scientific Publications. https://doi.org/10.1017/S0014479700023553

Haryjanto, L. (2009). Keragaman genetik cendana (Santalum album Linn) di Kebun Konservasi Ex-situ Watusipat, Gunungkidul dengan penanda isozim. Jurnal Pemuliaan Tanaman Hutan, 3(3), 127-138. https://doi.org/10.20886/jpth.2009.3.3.127138

Hettiarachchi, D. S. (2008). Volatile oil content determination in the Australian sandalwood industry: Towards a standardised method. Sandalwood Research Newsletter, (23), 1-4.

Howes, M.-J. R., Simmonds, M. S. ., \& Kite, G. C. (2004). Evaluation of the quality of sandalwood essential oils by gas chromatography-mass spectrometry. Journal of Chromatography A, 1028(2), 307-312. https://doi.org/10.1016/j.chroma.2003.11.093

ISO 3518. (2002). Oil of sandalwood (Santalum album L.). International Organization for Standardization.

IUCN. (1998). IUCN Red List of Threatened Species.

Janarthanam, B., Dhamotharan, R., \& Sumanthi, E. (2012). Thidiazuron ( TDZ ) - induced plant regeneration from internodal explants of Santalum album L. Journal of Biosciences Research, 3(3), 145-153.

McKinnel. (1993). Review on Santalum. Australia: IUFRO.

Misra, B. B., Das, S. S., \& Dey, S. (2013). Volatile profiling from heartwood of East Indian sandalwood tree. Journal of Pharmacy 
Research,

$7(4)$,

299-303.

https://doi.org/10.1016/j.jopr.2013.04.030

Moniodis, J., Jones, C. G., Plummer, Julie, A., Emilio, G., Barbour, L. L., \& Bohlmann, J. (2012). Chemical diversity and biosynthesis of Australian sandalwoods' (Santalum spicatum) essential oil. In International Sandalwood Symposium. Honolulu, Hawai: International Sandalwood Foundation.

Peeris, M., \& Senarath, W. (2015). In vitro propagation of Santalum album L. Journal of the National Science Foundation of Sri Lanka, 43(3), 265-272. https://doi.org/10.4038/jnsfsr.v43i3.7954

Quémin, C. (1988). Etudes sur le Santal (Santalum austrocaledonicum). Nouméa. Retrieved from http://agritrop.cirad.fr/319731/

Ratnaningrum, Y. W. N., \& Indrioko, S. (2014). Variation on genotypes and flowering characters affecting pollination mechanisms of Sandalwood (Santalum album Linn, Santalaceae ) Planted on ex-situ gene Conservation in Yogyakarta , Indonesia. Eurasian Journal of Forest Research, 17(1), 19-34.

Rugkhla, A., \& Mccomb, J. (1993). Self and cross pollination in Santalum spicatum and $S$. album. Sandalwood Research Newsletter, (1), $2-3$.

Sanjaya, Bagyalakshmi, M., Thrilok, S. R., \& Vittal, R. (2006a). Factors influencing in vivo and in vitro micrografting of sandalwood (Santalum album L.): an endangered tree species. Journal Forest Reseach, 11(3), 147-151. https://doi.org/10.1007/s10310-005-0208-1

Sanjaya, Bagyalakshmi, M., Thrilok, S. R., \& Vittal, R. R. (2006b). Micropropagation of an endangered Indian sandalwood (Santalum album L.). Journal Forest Reseach, 11(3), 203-209. https://doi.org/10.1007/s10310006-0207-x
Singh, C. K., Raj, S. R., Patil, V. R., Jaiswal, P. S., \& Subhash, N. (2013). Plant regeneration from leaf explants of mature sandalwood (Santalum album L.) trees under in vitro conditions. In In Vitro Cellular \& Developmental Biology. https://doi.org/10.1007/s11627-013-9495-y

Sinha, R. L. (1961). Sandal in Bundelkhand Forest Division, Uttar Pradesh. Indian Forester, 87(10), 590-597. Retrieved from http://www.indianforester.co.in/index.php/ind ianforester/article/view/24578

Subasinghe, S. . M. C. U. P. (2013). Sandalwood research: A global perspective. Journal of Tropical Forestry and Environment, 3(1), 18.

Subasinghe, U., Gamage, M., \& Hettiarachchi, D. S. (2013). Essential oil content and composition of Indian sandalwood (Santalum album) in Sri Lanka. Journal of Forestry Research, 24(1), 127-130. https://doi.org/10.1007/s11676013-0331-3

Sumardi, \& Fiani, A. (2015). Keragaman genetik cendana (Santalum album) dan tindakan reintroduksi ke Nusa Tenggara Timur Genetic diversity of sandalwood (Santalum album) and reintroduction to East Nusa Tenggara. In Seminar Nasional Masyarakat Biodiversitas Indonesia (Vol. 1, pp. 409-412). https://doi.org/10.13057/psnmbi/m010304

Xiaojin, L., Daping, X., Zengjiang, Y., Ningnan, Z., \& Yang, L. (2011). Preliminary analysis of growth and oil composition from a 6-year-old sandal (Santalum album L.) plantation in Gaoyao, Guangdong, south China. Sandalwood Research Newsletter, (26), 1-5. 
Jurnal Pemuliaan Tanaman Hutan

Vol. 11 No. 1, Juni 2017, p. 77 - 85 